\title{
The impact of faults on the hydrogeological conditions in the Roer Valley Rift System: an overview
}

\author{
V.F. Bense' ${ }^{1}$, R.T. Van Balen \& J.J. De Vries \\ Vrije Universiteit Amsterdam - Faculty of Earth and Life Sciences - De Boelelaan 1085, \\ 1081 HV Amsterdam, the Netherlands; e-mail: benv@geo.vu.nl \\ 1 Corresponding author
}

Manuscript received: January 2002; accepted: January 2003

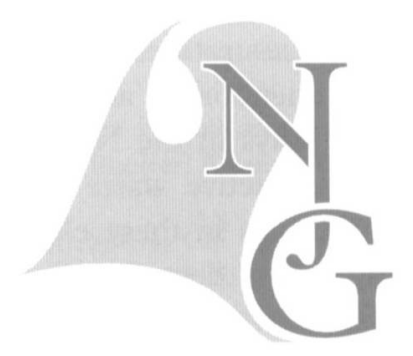

\begin{abstract}
The hydrogeology of the Roer Valley Rift System is strongly influenced by the hydraulic properties of faults. The hydrogeological impact of faults is illustrated by examples from the SE Netherlands and the adjacent lignite mining areas within the Roer Valley Rift System, near Bonn in Germany. Hydraulic head discontinuities over the main faults in the latter area can be up to tens of meters as a result of extremely large groundwater extractions in combination with the relatively low conductivity of the main faults. Within the Netherlands, outside the mining areas, such large groundwater extractions do not take place, and groundwater fluxes are smaller. In this situation natural hydraulic head differences over the main faults are limited to several meters. Hydraulic head profiles over faults provide a first estimate of fault hydraulic properties that can be quantified using simple analytical solutions. The impact of faults on near surface processes is reflected in vegetation patterns and the structure of drainage networks, aquifer structure and hydraulic head patterns. Faults can thus be of great influence on transport processes in the subsurface as well as on water-related phenomena at the surface, and should accordingly be taken into consideration in studies related to water-management, contamination and environmental impact. Faults that have an enhanced vertical permeability are difficult to detect when horizontal groundwater flow is studied, which is probably the main reason why they are rarely described. Though, these faults may form important preferential paths to vertical groundwater flow.
\end{abstract}

Keywords: Hydrogeology, faults, RoerValley Rift System, the Netherlands

\section{Introduction}

The Roer Valley Rift System (RVRS) is located in the southeastern part of the Netherlands and adjacent parts of Belgium and Germany (Fig. 1).

The Roer Valley Rift System forms the southeastern part of the North Sea Basin which is part of a Cenozoic mega-rift system crossing western and central Europe (Ziegler, 1994). It has a complex Mesozoic and Cenozoic tectonic history, comprising several extension and inversion phases. The current extension phase started during the Late Oligocene (Geluk et al., 1994). The Roer Valley Rift System comprises four main structural elements: the northern part of the Campine Block in the south, the Roer Valley
Graben in the center, and the Peel Block and Venlo Block in the northeast (Fig. 2).

The Roer Valley Graben is separated from the adjoining blocks by the Feldbiss Fault Zone in the south and by the Peel Boundary Fault Zone in the north. In the area of investigation these are the most active fault zones during the Quaternary (e.g. Paulissen et al., 1985; Houtgast \& Van Balen, 2000). The central Roer Valley Graben is filled with up to $1200 \mathrm{~m}$ of Late Oligocene - Recent sediments comprising finegrained marine deposits overlain by a relatively thin sequence $(\leq 50 \mathrm{~m})$ of medium to coarse grained fluvial-deltaic deposits of Pleistocene age. The same sequence has a total thickness of up to $200 \mathrm{~m}$ on the Peel Block (Geluk et al., 1994). The coarse grained 


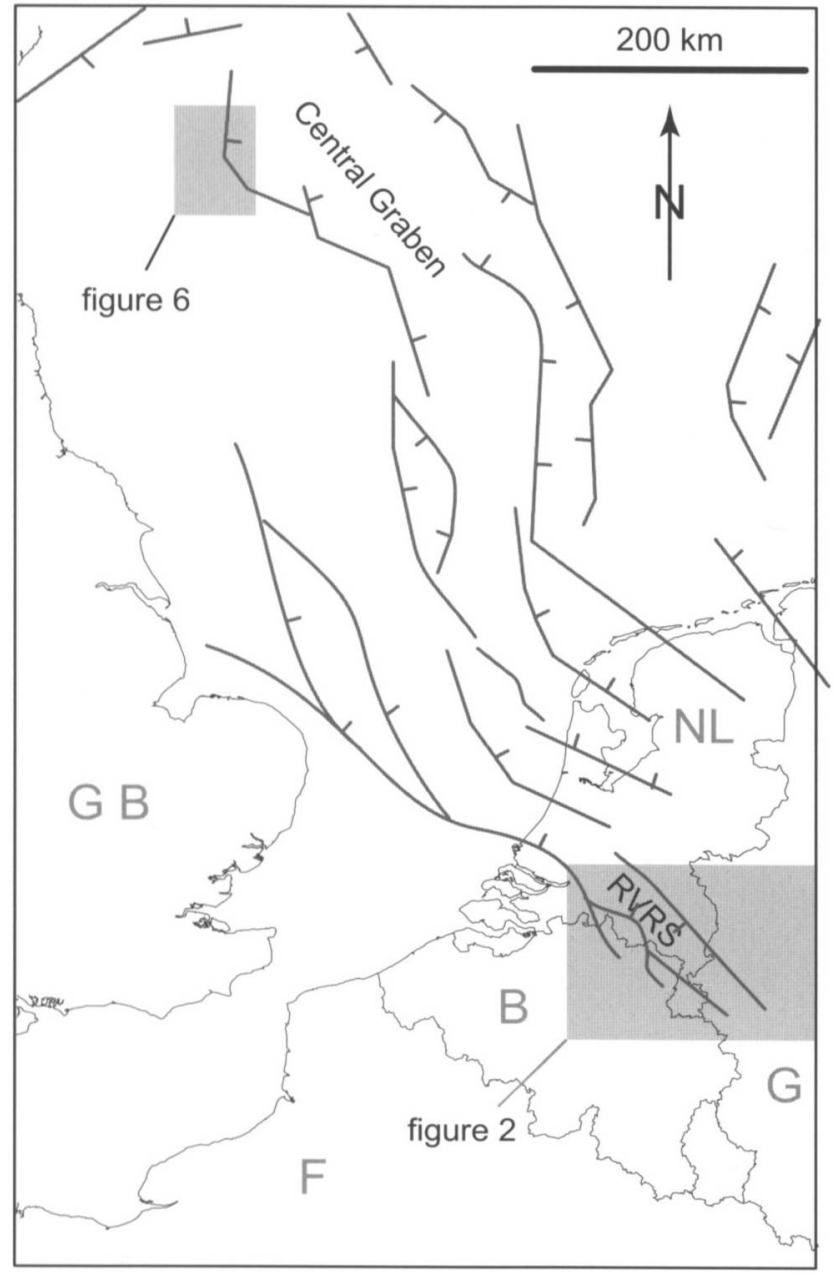

1 fault line

Fig. 1. Structural overview map of the North Sea Basin (after Knott, 1993; Ziegler, 1994). RVRS = Roer Valley Rift System, GB $=$ Great-Britain, $\mathrm{G}=$ Germany, $\mathrm{B}=$ Belgium, $\mathrm{NL}=$ The Nether lands, $\mathrm{F}=$ France. fluvial deposits at the top of the sequence form the main aquifer in the study area.

In general, faults in the unconsolidated sediments in the Roer Valley Rift System appear to represent a barrier to horizontal groundwater flow. In addition, faulting has induced a stepped morphology, through small fault scarps. Fig. 3 illustrates the case that groundwater, moving from a topographically more elevated block to a lower area, has to pass a low-conductivity fault zone.

In such a situation, a high groundwater table in the upstream area is found, together with a high hydraulic gradient over the fault line. Where the groundwater table intersects the topography, the groundwater outcrop zone will be an area with sapping erosion. Differences in bank erodibility and stream deflection are other possible aspects of interaction between faults, morphology and hydrology (De Vries, 1974, 1994; Vandenberghe, 1990). It should be emphasized that smallscale variations in topography and soil permeability normally have a large influence on near surface hydrological conditions in areas with a shallow groundwater table. This is due to the fact that small scale variations in relief under such conditions cause relatively large variations in groundwater depth and thus in storage and buffering capacity which in turn enhances the differentiation in bear surface processes like erosion and soil formation (DeVries, 1994). This applies to most of the Netherlands where this interaction is strongly reflected in the increase in drainage density with decreas-

Fig. 2. The Roer Valley Rift System (RVRS) with locations of sites as discussed in the text. RVG $=$ Roer Valley Graben, $V B=$ Venlo Block, $\mathrm{PB}=$ Peel Block, $\mathrm{CB}=$ Campine Block, $\mathrm{EB}=$ Erft Block.

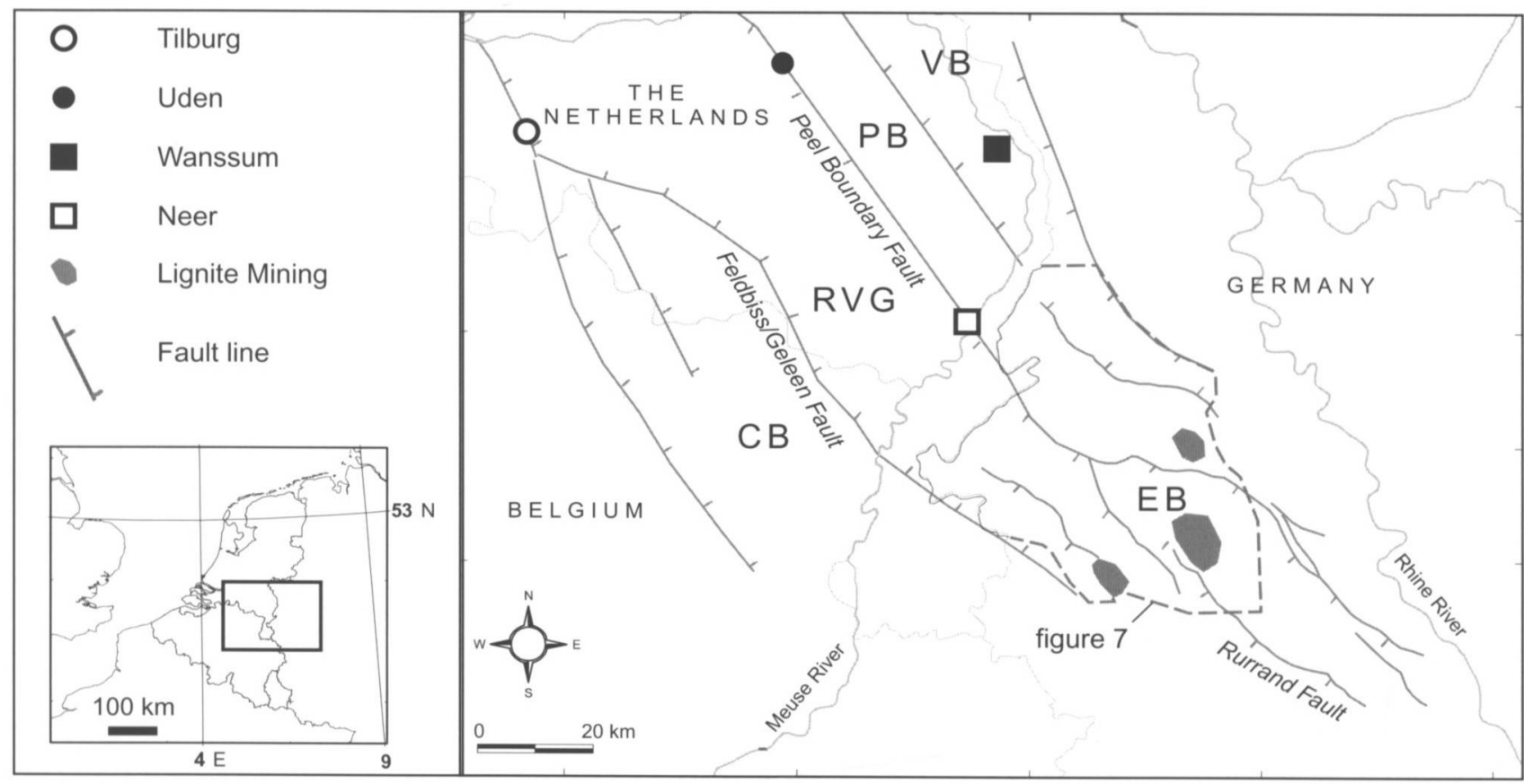



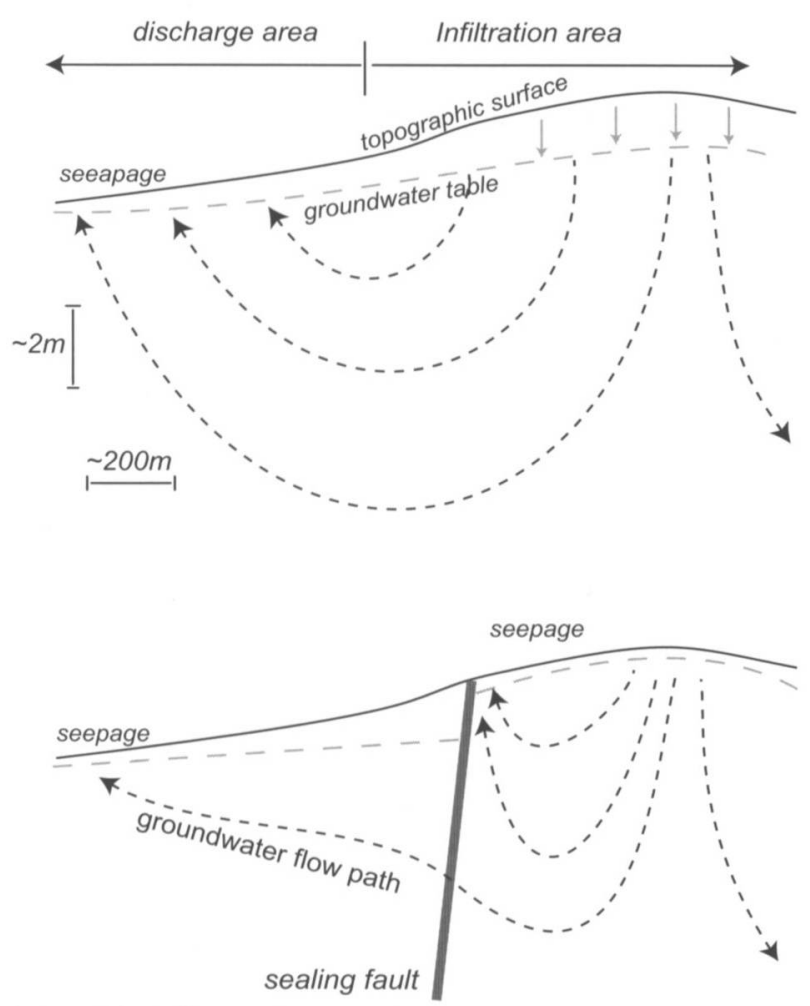

Fig. 3. The difference between shallow hydrological systems as a result of the presence of a low conductivity fault zone in the subsurface.

ing groundwater depth (DeVries, 1974, 1994).

A striking example of how a fault can influence the local hydrological situation is illustrated by aerial photographs of the vicinity of the city of Tilburg (Fig. 4). The northward extension of the Feldbiss Fault Zone, here called the Gilze-Rijen Fault Zone, cuts through farming land. The eastern part of this land has a higher soil moisture content (darker tone on the image) than the western part. In this case, juxtaposition rather than the hydraulic properties of the fault zone it self, is the cause for the observed soil moisture patterns. It is evident that such contrasts can lead to considerable differences in crop yield between the different parts of this plot. The hydrogeological situation at this location will be discussed in more detail below.

The impact of small-scale topographical features on the groundwater flow pattern reduces with depth. The vertical penetration of the influence of topographic undulations as well as the vertical propagation of groundwater level oscillations in general increases with the wavelength and amplitude of the topographic phenomena (Zijl, 1993).

The aim of this paper is to present an overview and synthesis of the influence of rift-related faults on the hydrogeological conditions of the Roer Valley Rift System. In addition, an example from the geologically related North Sea Basin is given (Fig. 1). The examples and results from recent field studies, make clear that the impact of faults is strongly scale dependent. In this paper, it is first discussed how the hydraulic properties of faults can be quantified. Next, several examples are presented of fault-induced groundwater flow perturbations at different length scales, ranging from $100 \mathrm{~km}$ to $1 \mathrm{~m}$. Finally, we will discuss the results and propose a few generalized conclusions and their implication to practical problems dealing with groundwater flow in areas where faults are cutting through unconsolidated sediments.

\section{Hydraulic characterization of fault zones}

The most straightforward way to parameterize the hydraulic properties of a fault zone is to calculate its specific resistance (c $[\mathrm{T}])$ to flow perpendicular to the fault zone (i.e. across the fault). The resistance of a fault in that case, is here defined as the ratio of the fault zone width ( $\boldsymbol{w}[\mathrm{L}])$ and the bulk hydraulic conductivity $\left(\boldsymbol{K}\left[\mathrm{LT}^{-1}\right]\right)$ of the fault zone material;

$$
c=\frac{w}{K} \quad[\mathrm{~T}]
$$

The rate of horizontal groundwater flow through an aquifer that has thickness $\boldsymbol{D}[\mathrm{L}]$, length $\boldsymbol{L}[\mathrm{L}]$, and a hydraulic conductivity in the direction of flow $\boldsymbol{K}$ $\left[\mathrm{LT}^{-1}\right]$, is given by Darcy's Law:

$$
q=-K D \frac{\Delta h_{L}}{L} \quad\left[\mathrm{~L}^{2} / \mathrm{T}\right]
$$

where $\Delta \boldsymbol{h}_{\boldsymbol{L}}[\mathrm{L}]$ is the hydraulic head difference over distance $\boldsymbol{L}$. When $\boldsymbol{L}$ equals $\boldsymbol{w}$ and continuity of flux exists over the fault zone, combination of equation (2) and equation (1) gives the resistance of a fault zone: where $\Delta \boldsymbol{h}_{\text {fault }}$ is the hydraulic head difference over the fault.

$$
c=D\left|\frac{\Delta h_{\text {faut }}}{q}\right|
$$

The specific flow resistance to flow perpendicular to the fault zone is the most general form to characterize the hydraulic properties of a fault zone as they are lumped into one parameter. On the other hand, the regional context can be considered using the transmissibility of the fault zone $\left(\boldsymbol{T}\left[\mathrm{L}^{2} \mathrm{~T}^{-1}\right]\right)$ that equals the product of the vertically averaged hydraulic conductivity $(\boldsymbol{K})$ and the thickness of the aquifer $(\boldsymbol{D})$ over the fault zone.

$$
T=K D \quad\left[\mathrm{~L}^{2} \mathrm{~T}^{-1}\right]
$$

The relation between specific resistance of the fault zone $\boldsymbol{c}$ and its transmisibility $\boldsymbol{T}_{f}$ is:

$$
c=\frac{D}{T_{f}} w
$$

where $w[\mathrm{~L}]$ equals the fault zone thickness 


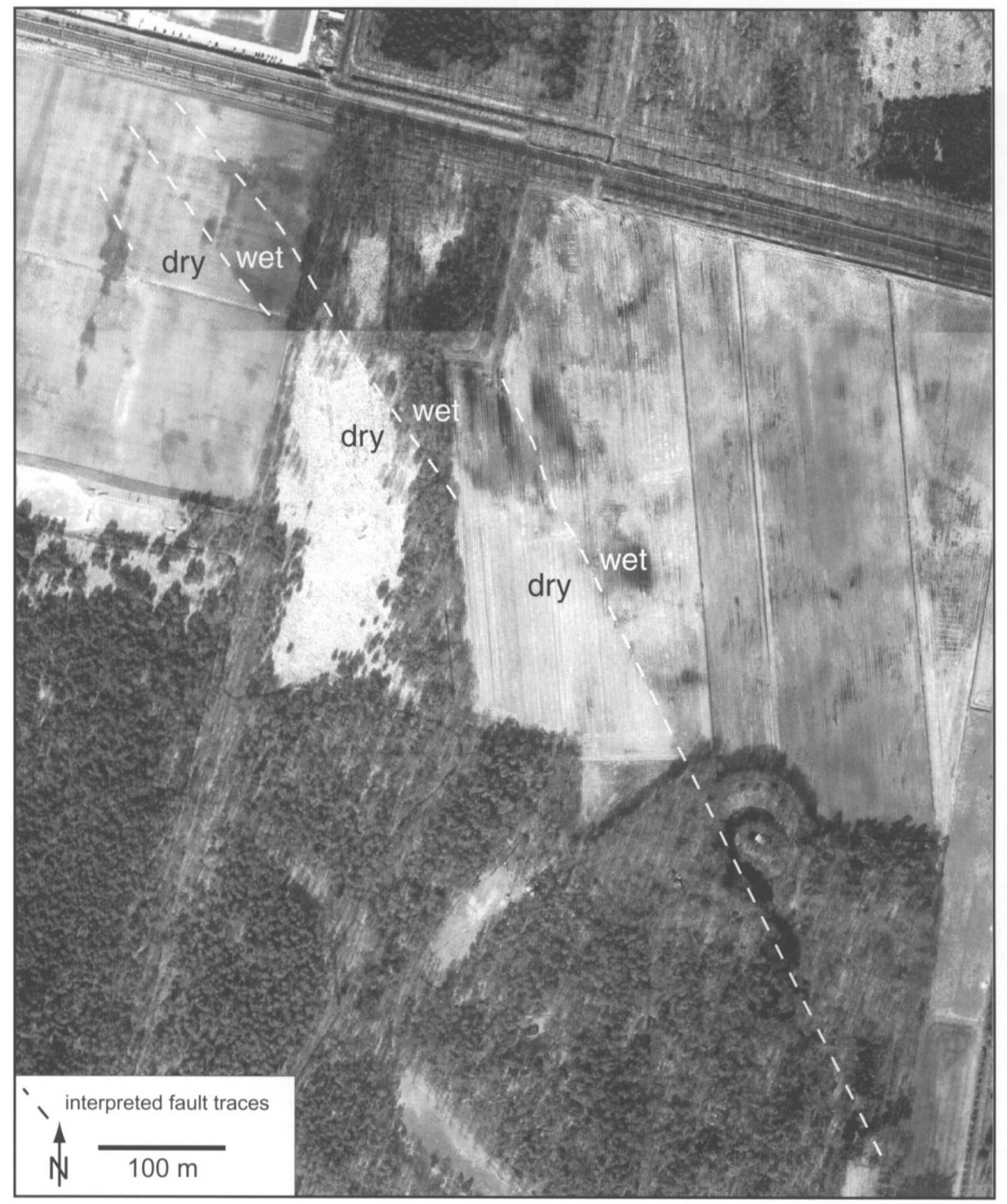

Fig. 4. Aerial photograph of the Gilze-Rijen fault as it crosses farming land near the city of Tilburg (with permission of the municipality of Tilburg). The fault clearly separates different hydrologic units; for location see Fig. 14.

Haneberg (1995) used the latter approach to calculate the hydraulic head profile over an aquifer that is cut by a fault zone (Fig. 5 ).

Three flow domains can be distinguished; the transmisibility of the left hand side block of the fault $\left(\boldsymbol{T}_{l}\right)$, the transmissibility of the fault zone itself $\left(\boldsymbol{T}_{f}\right)$ and the transmissibility of the right hand side block $\left(\boldsymbol{T}_{r}\right)$. If exchanges of water with underlying aquifer systems or the surface drainage system are negligible, steady-state conditions require continuity of flux over the series of flow domains so that $\boldsymbol{q}_{l}=\boldsymbol{q}_{\text {fault }}=\boldsymbol{q}_{\mathrm{r}}$. This implies for one-dimensional flow within each flow domain (Fig. 5):

$$
d^{2} h / d x^{2}=0
$$

Under confined conditions and for a constant thickness of the aquifer, solutions for (6) show that the hy- draulic gradient $i$ over each part of the aquifer system is linear, thus:

$$
T_{r} i_{r}=T_{f} i_{f}=T_{l} i_{l}
$$

If recharge or discharge is taking place to or from the fault zone equation (6) changes to:

$$
d^{2} h / d x^{2}=-\frac{R_{f}}{T_{f}}
$$

Where $\boldsymbol{R}_{f}\left[\mathrm{LT}^{-1}\right]$ represents the rate of recharge $\left(\boldsymbol{R}_{f}\right.$ $>0)$ or discharge $\left(\boldsymbol{R}_{f}<0\right)$ to or from the fault zone.

Figure 5 illustrates a head profile under confined conditions for the case that $\boldsymbol{T}_{f}<<\boldsymbol{T}_{r}<\boldsymbol{T}_{l}$ and $\boldsymbol{R}_{f}=0$. Since continuity of flux exists between each domain, the ratio between two aquifer transmissivities is inversely proportional to the ratio of the aquifer gradients. In order to produce a high enough gradient over 

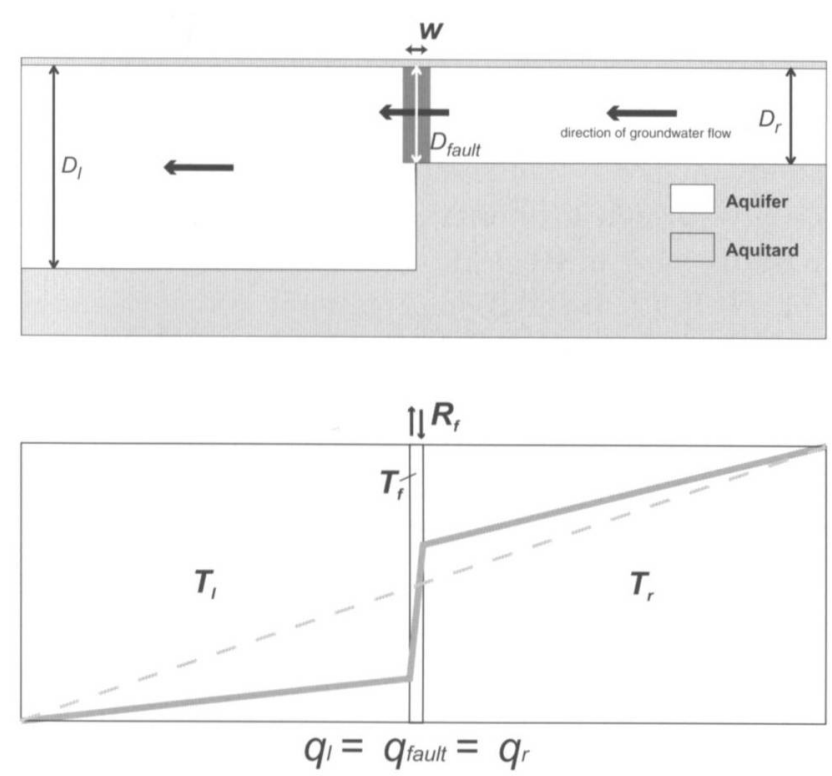

Fig. 5. Schematized aquifer structure over which the hydraulic head profile can be described using a simple analytical approach $\left(\boldsymbol{T}_{l}>\boldsymbol{T}_{r}>>\boldsymbol{T}_{f}\right)$

the fault zone to satisfy a constant flux, an up-gradient head excess is produced relative to the undisturbed situation, i.e. if no fault was present in the system. In the left-hand aquifer the same principle results in a loss of head relative to the undisturbed head gradient. If the topographic conditions are not in agreement with these required gradients continuity of flux can be lost. Groundwater will discharge near the fault zone if the topography lowers towards the fault zone in the right hand system (Fig. 5).

If transmissibility ratios are estimated from the hydraulic gradients on both sides of a fault zone, and the fault zone width $(\boldsymbol{w})$ can be estimated as well, the actual value of fault zone transmissibility can be calculated from one independent observation of the magnitude of the transmissibility of the aquifer on one side of the fault zone. Although this description of hydraulic head profiles over idealized faults is in principle simple, in most cases it requires many field observations to obtain enough information for a more complex interpretation of groundwater flow through a fault zone.

The impact on the hydraulic head profile is less significant when a fault zone has a higher transmissibility than the flanking aquifers. This is because flow across a high-transmissibility zone is limited by the ability of the up-gradient aquifer to supply a sufficient amount of water to maintain the flux through the fault zone. In this case the gradient in the fault zone will be lower than in the flanking aquifers and therefore will have less impact on the gradient in the flanking aquifers than when the fault is a relatively low transmissibility zone. This effect may be one of the reasons that, as in this paper, faults that form barriers to groundwater flow are more frequently reported on than faults being highly transmissive zones. Though, faults forming a barrier to horizontal groundwater flow may simultaneously act as important pathways to vertical groundwater flow as will be illustrated in the following sections.

\section{Examples of the impact of faults on groundwa- ter flow patterns}

Most researchers focusing on the migration and trapping of hydrocarbons are well aware of the importance of faults to the subsurface hydrogeological conditions. For example, faults that bound pore water pressure cells and form seals to hydrocarbon accumulations are a common and well-studied phenomenon in the North Sea Basin e.g. (Knott, 1993; Van Balen et al., 2000). Since the Roer Valley Rift System forms the southernmost, onshore part of the North Sea Basin (Fig. 2), the hydrogeologic properties of faults at larger depths as inferred from hydrocarbon exploration and production data will be discussed in the first section. Subsequently, several onshore cases where faults are clearly expressed in the hydrogeology of the Roer Valley Rift System are discussed.

Regional scale $(>10 \mathrm{~km})$

Sealing faults at large depths in the RoerValley Rift System In the northwestern part of the Roer Valley Rift System several oil and gas accumulations are situated in fault bounded Triassic sandstone reservoirs (Winstanley, 1993). In this case the sealing behavior of the faults can be largely explained by juxtaposition of reservoir rock, i.e. sandstones against Jurassic claystones. These faults are part of the same larger rift system as the pressure sealing faults in the Central Graben.

Geological structure from basin-scale to the local scale has a primary control on the distribution of overpressure in the Central Graben of the North Sea (Darby et al., 1996; Fig. 6).

The two principal mechanisms explaining the sealing capacity of faults in this area are smearing of clay along the fault plane due to the faulting process and juxtaposition of lithologies that have strongly contrasting conductivities (e.g. shale vs. sandstone) (Knott, 1993). In addition, according to Harper \& Lundin (1997) a close relation exists between the orientation of cell-bounding faults and the present-day stress field. There are no sealing faults parallel to the NW-SE directed maximum horizontal stress, whereas the main strike orientations of the sealing faults are NNW-SSE and E-W. 


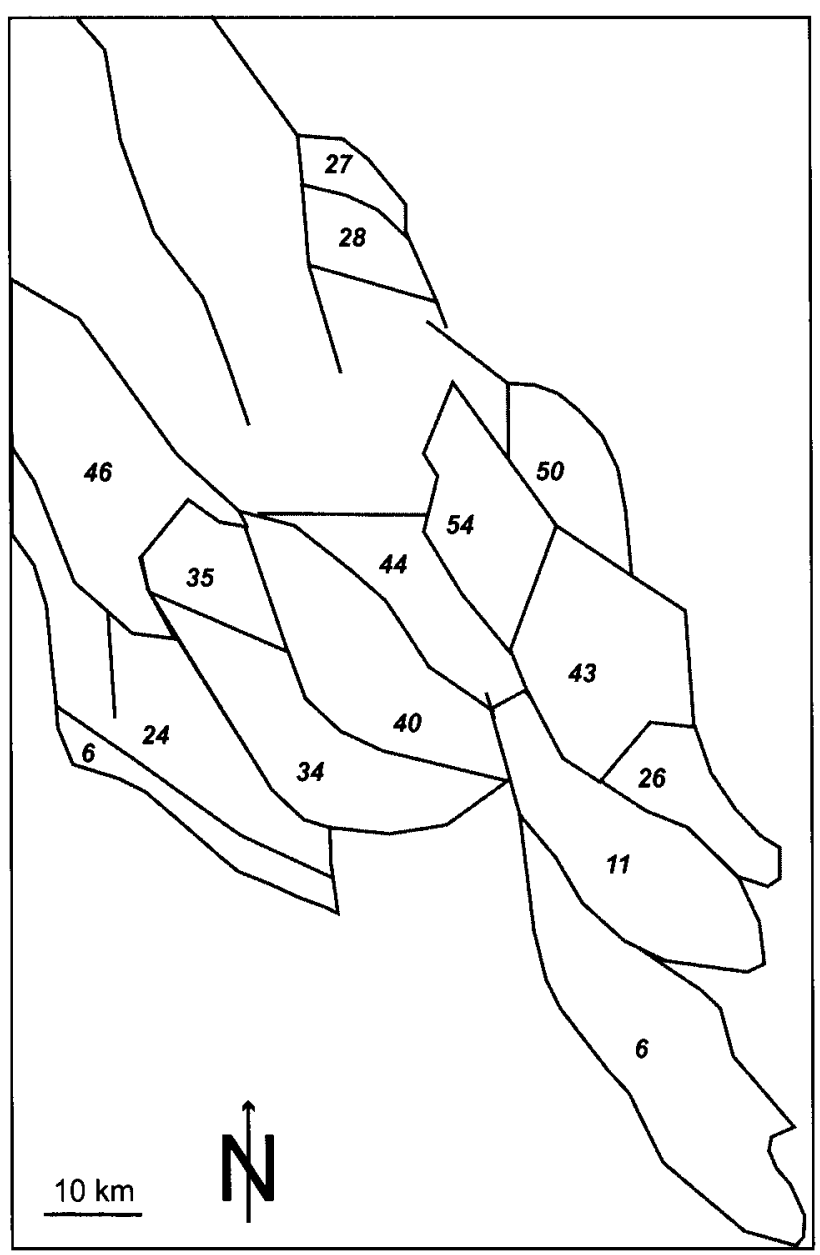

Fig. 6. Fault bounded pressure cells in the Central Graben of the North sea basin at a depth of around 3.5 kilometer; numbers indicate the amount of overpressure in $\mathrm{MPa}$, after Darby et al. (1996).

\section{Lignite mining area in Germany}

The pattern of the hydraulic head distribution in deeper aquifers of the lignite mining area within the German part of the Roer Valley Rift System is very similar to the distribution of pressure in the Central Graben in the North Sea basin. In the lignite mining area, the origin of the head difference between the tectonic blocks is the result of large groundwater extractions and the low hydraulic transmissibility of the main faults. The complex interplay of faults with groundwater flow in the lignite mining area is documented in greater detail than usual for hydrocarbon reservoir studies (compare for example Figs. $6 \& 7$ ). Fig. 7 shows the hydraulic head distribution in one of the deeper confined aquifers in the lignite mining area.

Mining for lignite takes place in open pits of around $300 \mathrm{~m}$ deep. In order to construct mines to these depths, groundwater levels must be below the level of mining. This is realized through large groundwater extractions of which the most important well fields are indicated on Fig. 7. The lowering of the groundwater levels has resulted in hydraulic head patterns that reveal that a great variation in fault permeability must exist. Some faults are sealing, causing locally very high hydraulic head gradients. Others appear to have little or no visible impact on the hydraulic head distribution. Hydraulic properties vary between individual faults but can also vary along the strike of a single fault. Like in hydrocarbon studies, factors that can explain these variations are the geometry of the fault zone, which depends on the fault throw, fault orientation, aquifer thickness, and the efficiency of fault zone processes, such as clay smearing and cataclasis. Wallbraun (1992) quantified the observed fault hydraulic resistance at various locations using numerical simulations. He did this for the aquifer for which isolines of hydraulic head are shown in Fig. 7. The resistance of the 'Lövenicher' fault zone was calculated to be $\sim 770$ days, while the 'Kaster' fault zone, which has a throw of the same magnitude showed a resistance of $\sim 190$ days at this level (for locations, see Fig. 7). The lowering of groundwater levels within the Erft Block resulted in hydraulic head differences of more than $50 \mathrm{~m}$ over the Rurrand Fault along the NW boundary of the Erft Block. The sealing capacities of the Rurrand Fault cause the gradual decline of groundwater levels in the Erft Block to have only a limited effect on the hydraulic head distribution within the Roer Valley Graben. Further south, directly adjacent to the 'Hambach' open-pit mine, the Rurrand Fault is segmented where relay zones are present which transfer strain between the fault segments (c.f. Willemse et al, 1996). This specific discontinuity in the Rurrand Fault is directly visible in the hydraulic head pattern of the Roer Valley Graben since at this location the extraction cone on the Erft Block continues into the Roer Valley Graben. Apparently, the sealing potential of the Rurrand Fault is strongly lowered by the segmentation structure and at this location groundwater flow exploits the relay zone between the fault segments to flow into the Erft Block. Detailed mapping of hydraulic head patterns combined with the extensively available geological information over the area is needed to better explain the observed variation in hydraulic properties of the individual faults (Wallbraun, 1992).

The spectacular hydraulic head gradients over the Rurrand Fault continue to exist as long as the flux is maintained through groundwater extractions. If these extractions will cease, the strong hydraulic gradient will reduce to a gradient that is in accordance with the natural groundwater flow distribution. The effect of the lignite mining activities on the hydraulic head in the deeper aquifers in the Netherlands is subject of 


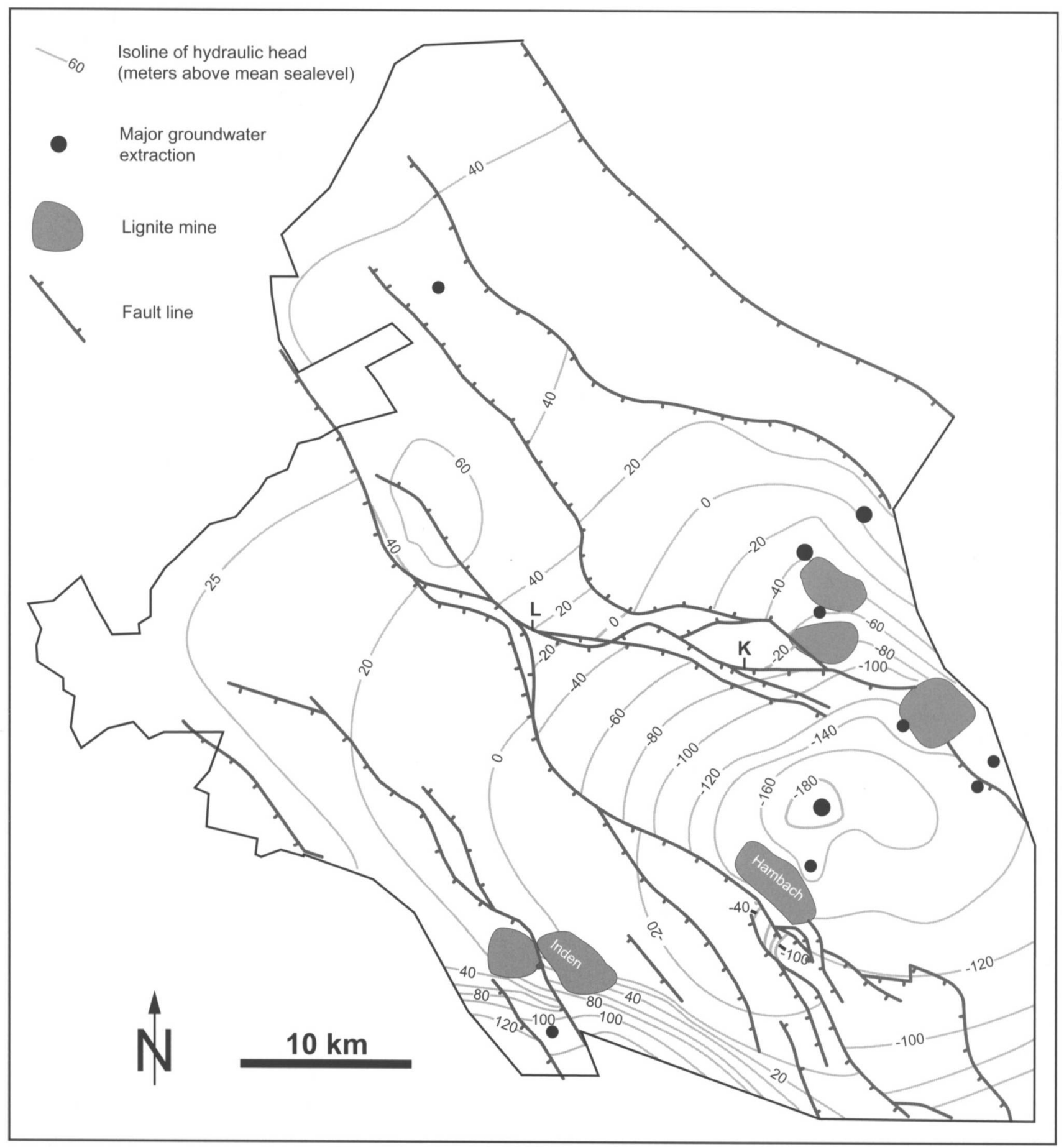

Fig. 7. Hydraulic head pattern in the lignite mining area in middle deep aquifers. The pattern is the result of huge groundwater extractions (redrawn after Wallbraun, 1989). K = section over the Kaster Fault; $\mathrm{L}=$ section over the Lövenicher Fault.

ongoing research (e.g. Stuurman, 2000). However, it is clear that due to the presence of the sealing faults in the mining area this effect is strongly attenuated.

In the Netherlands, groundwater extractions on the scale of that in the lignite mining area do not occur. Yet, the faults of the Roer Valley Rift System still have a considerable impact on groundwater flow and aquifer structure in the Netherlands, as will be shown in the next sections.

\section{Field scale $(\sim k m)$}

\section{The Gilze-Rijen Fault near the city of Tilburg}

The Gilze-Rijen fault forms the northward extension of the Feldbiss Fault Zone. An aerial photograph taken in the spring of 1997 near the city of Tilburg shows a section of the Gilze-Rijen fault, where it crosses farming land (Fig. 4). The soil moisture distribution within the farming land is fully correlated with the fault trace. Dark colors in NE of the fault represent a 
relatively higher soil moisture content. The Gilze-Rijen fault zone that separates the two different domains, is only a few meters wide.

The soil map of the Netherlands (Fig. 8; STIBOKA, 1985) shows that at the location of the aerial photograph (Fig. 4) the fault line separates two different soil types. On the footwall block, coarse sands occur at or near the surface (Sterksel Formation), while on the hanging wall at the eastern side of the fault

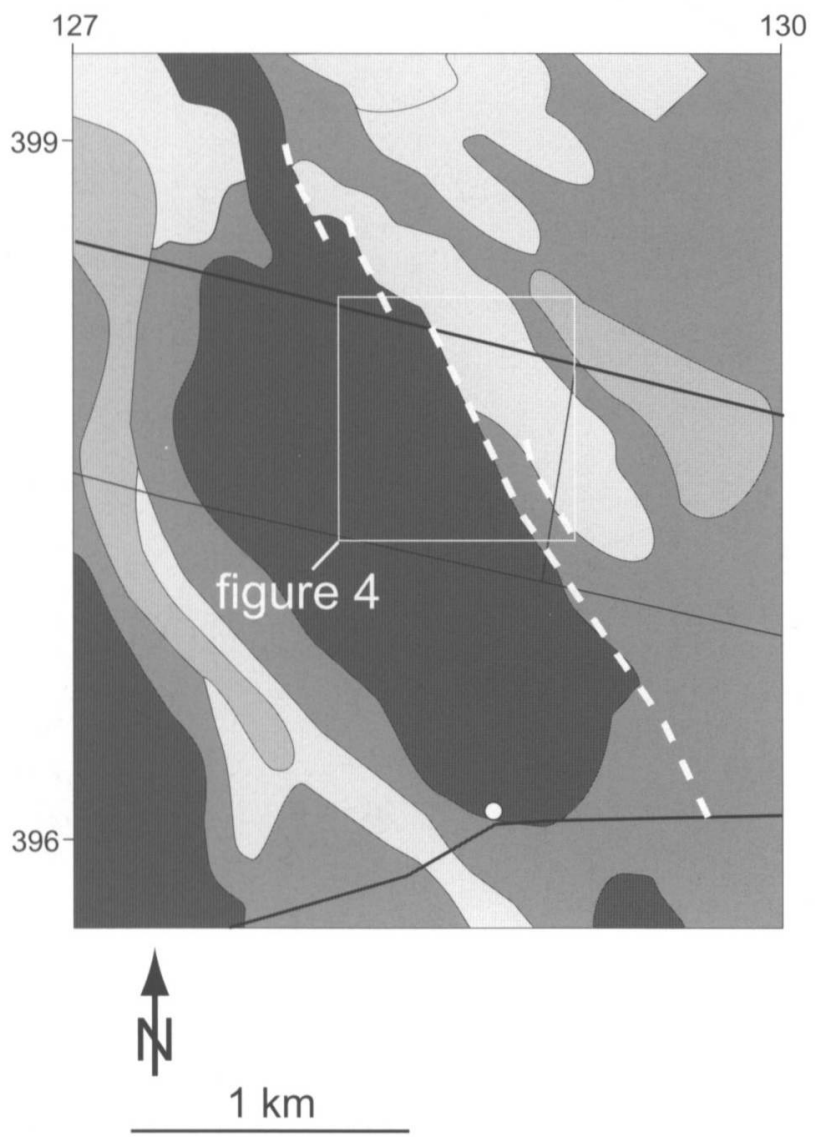

loamy (fine) sand
sand
coarse sand
fine sand
interpreted fault traces
on basis of the soil map
main pumping station of the Tilburg
Water Supply Company

Fig. 8. Detail of the soil map of the Netherlands that shows the overstepping structure of the Gilze-Rijen fault zone near the city of Tilburg; map coordinates in thousands of meters in the Dutch coordinate system. The downthrown block is on the eastern side of the fault trace. The pattern of fault traces as interpreted on basis of the soil map does not fully match the fault traces as interpreted on the aerial photograph (Fig. 4). Probably this discrepancy can be attributed to the uncertainties in the exact location of the borders between the different units on the soil map since these are interpreted on basis of point observations. fine sandy loams dominate (Nuenen Group). The same lithological contrast is found in a very detailed section that was made several kilometers to the south, on the terrain of the Water Supply Company of Tilburg (De Glee \& Brandenburg, 1926). The structure of the fault system in this area was further investigated by Vandenberghe, (1982) and subsequently by Van Zanten (1996). Both made use of geoelectrical prospecting methods in combination with borehole information. Vandenberghe (1982) showed that the Gilze-Rijen fault is the easternmost fault of a set of faults that form the western boundary of the Roer Valley Graben. Van Zanten (1996) suggests that the Gilze-Rijen fault consists of two closely spaced faults about 100 meters apart. However, the soil map (Fig. 8 ) and the more detailed aerial photograph of the area (Fig. 4) suggest that a system of overstepping faults is a more likely scenario for the Gilze-Rijen fault. In an overstepping system, relay zones, such as those observed in the lignite mining area in Germany, may cause discontinuities in the otherwise sealing behaviour of faults. Van Zanten (1996) showed connection between shallow and deeper groundwater along the faults in this area using tritium and chloride concentrations of water from deep aquifers.

\section{Small fault near the village of Wanssum}

During the late 1950 s and the early 1960 s research by the Institute of Land and Water Management Research (ICW) showed that faults on the Peel Block are associated with anomalous high hydraulic head gradients (Bon, 1968). On the Venlo Block near the Meuse River, a detailed hydrogeological profile based on boreholes and observation wells was constructed perpendicular to a secondary fault near the village of Wanssum (for location see Fig. 2; Ernst \& De Ridder, 1960). This study is probably the best-documented example in the Netherlands that shows the impact of a small fault on the local hydraulic head distribution (Fig. 9).

It shows that extremely detailed observations are needed to properly characterize the hydrogeological buildup of a sealing fault zone. Also, the small spacing of observation wells shows that the fault zone is only limited to $5 \mathrm{~m}$ at most. Ernst \& De Ridder (1960) estimated the specific resistance (c) on basis of their data on this fault zone to be around 350 days.

\section{The Peel Boundary Fault Zone near the village of Uden}

A study on a similar scale was done in the late 1990's, by Stuurman \& Atari (1997), on the eastern boundary of the Peel Block, across the Peel Boundary Fault Zone near the village of Uden (Fig. 2). Wet con- 


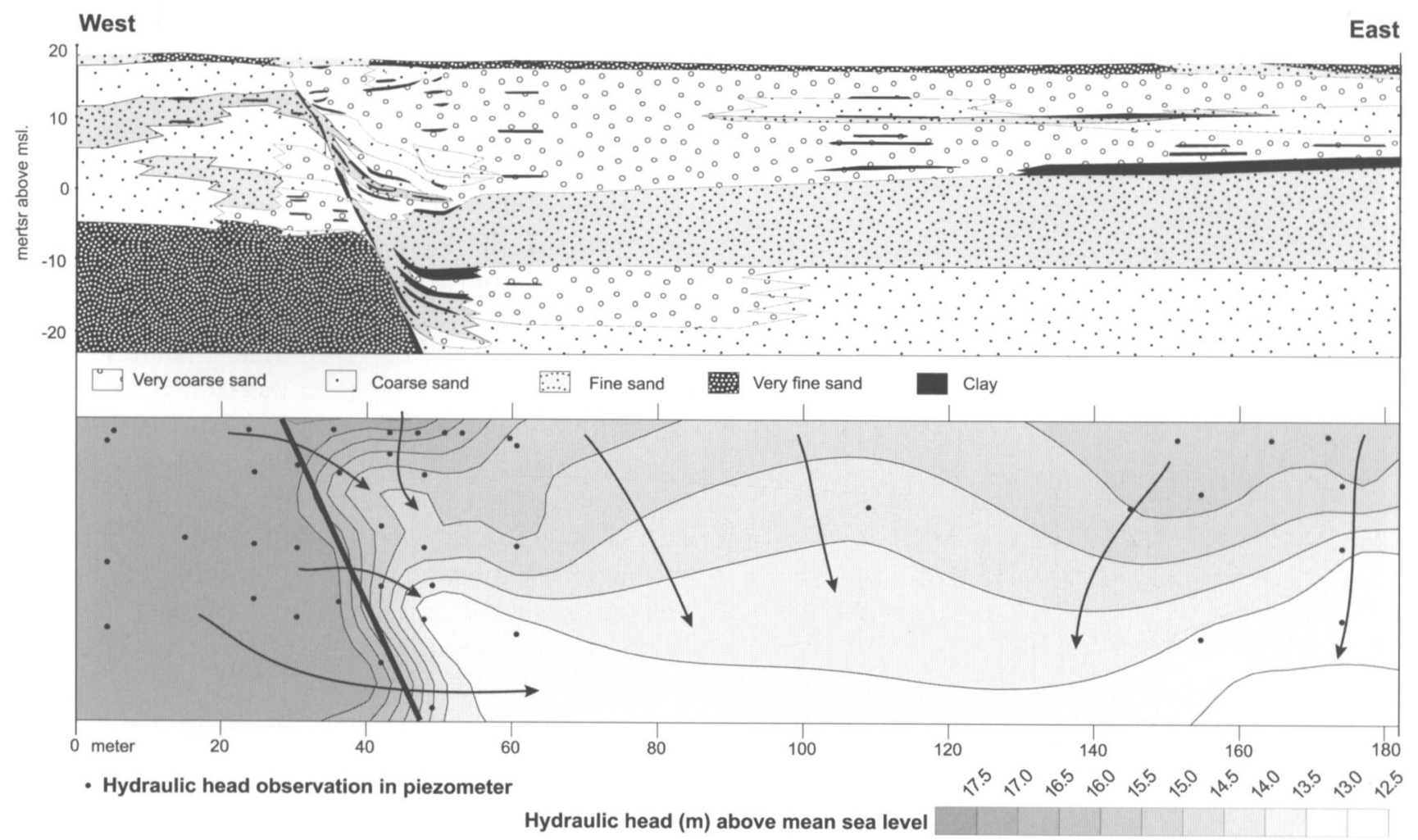

Fig. 9. Hydrogeological section and associated hydraulic head patterns over a fault near the village of Wanssum (after Ernst \& De Ridder, 1960); for location see Fig. 2.

ditions prevail on the topographic high of the Peel Block. Peat bogs developed from the beginning of the Holocene, when even wetter and warmer climatic conditions caused the groundwater table to rise to the surface. This anomalous hydrologic situation, with the wettest areas on the higher parts in the topography, was the motivation for earlier studies (e.g. Visser, 1948) that focussed on an improvement of the problematic water management of these areas.

A schematized hydrogeologic section (Fig. 10) shows how east of the Peel Boundary Fault Zone and along the fault scarp, iron-rich groundwater is discharging and is oxidized as soon as it approaches the surface. This process leads to iron-cemented sands and silts at these locations. The hydraulic head difference across the fault zone is about three meters, in the first aquifer below the phreatic zone. The width of the fault zone is estimated from lithological sections in Stuurman \& Atari (1997), as five meters. Fluvial sands and gravels of mid-Pleistocene age form the main aquifer (Veghel and Sterksel formations). On the Peel Block, these sediments overlay fine-grained marine sands of Miocene age (Breda Formation). In the Roer Valley Graben the hydrological base is formed by clays of Pleistocene age (Kedichem Formation). On top of this system silts and fine sands of aeolian origin were deposited during the Saalian and Weichselian (Nuenen Group). These latter deposits form the upper, phreatic aquifer. As a result of a faulted topography, the aeolian deposits are about 15 meters thicker in the Roer Valley Graben than on the higher Peel Block. At the surface, the Peel Boundary Fault Zone forms a topographic scarp of about $3 \mathrm{~m}$.

Csónka (1968) made a horizontal profile of groundwater temperature at a depth of $\sim 150 \mathrm{~cm}$ below the surface, which has been added to Fig.10. These measurements were done on one day during the spring of 1965 . His data show clearly that the seepage area on the footwall of the fault coincides with a zone of anomalously high groundwater temperatures. The observed anomaly of groundwater temperature may point to strong vertical groundwater flow from more than $100 \mathrm{~m}$ in this zone. Though, further analysis and measurements during different seasons are needed since the magnitude of the magnitude of the observed temperature anomaly is dependent on seasonal temperature fluctuations. Strong upward flow along the fault zone may indicate a strongly anisotropic permeability distribution within the fault zone. In such a model, the core of the fault forms a strong barrier to horizontal groundwater flow while a better permeable damage zone adjacent to the fault core may form a preferential path to vertical flow. Although the iron-cementation of the Peel Boundary Fault Zone led to a strong reduction of its permeability, this phenomenon is limited to the upper oxygen 


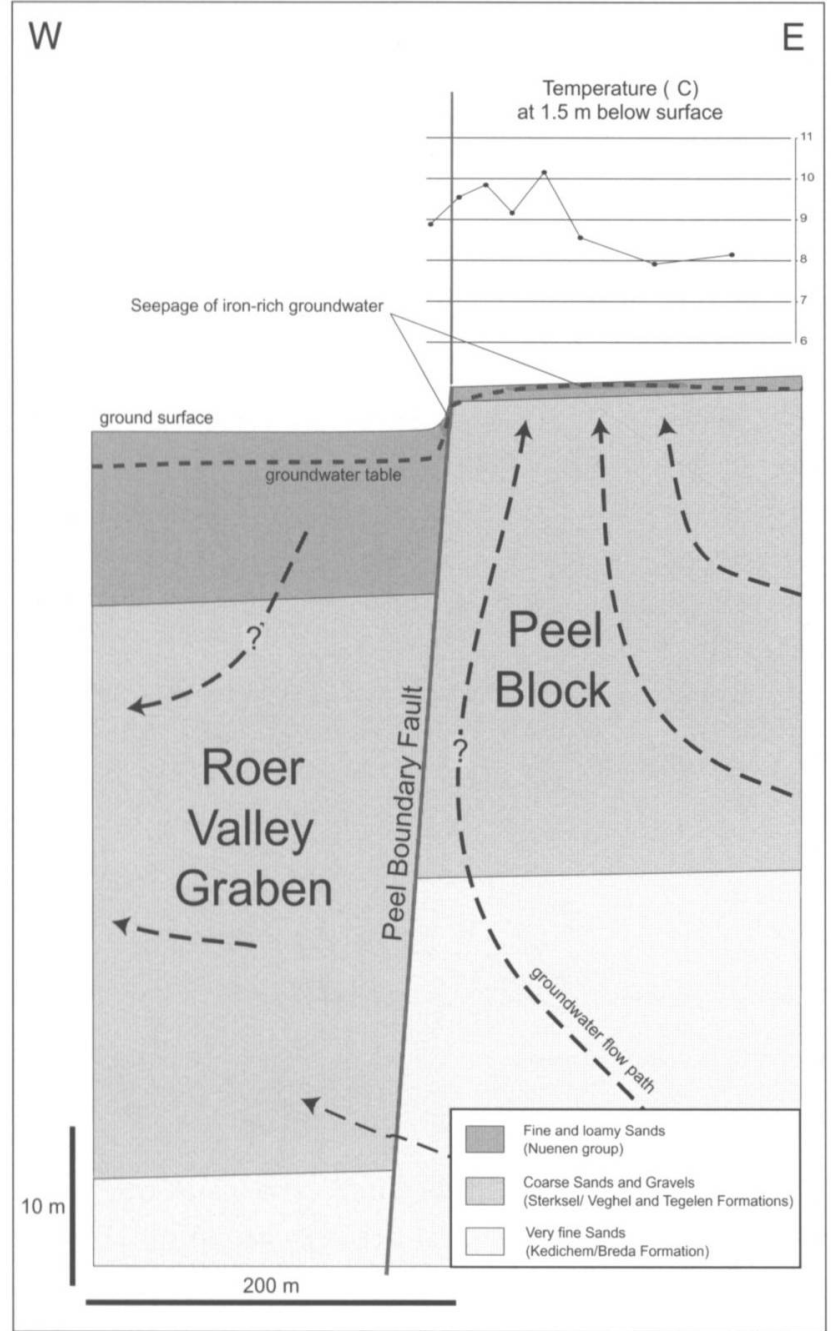

Fig. 10. Schematized hydrogeological section over the Peel Boundary Fault Zone near the village of Uden (compiled after Stuurman (1997)); for location see Fig. 2.

rich part of the aquifer and therefore cannot explain the high resistance of the Peel Boundary Fault Zone at larger depths, as indicated by the large drop in hydraulic head over the fault. Probably, mechanisms like clay smearing and juxtaposition of aquitards and aquifers will play an important role at those depths.

The resistance of the Peel Boundary Fault Zone can be calculated by analysis of the hydraulic gradients on the Peel Block $\left(\boldsymbol{i}_{\boldsymbol{P B}}\right)$, Roer Valley Graben $\left(\boldsymbol{i}_{\boldsymbol{R} V G}\right)$ and over the Peel Boundary Fault Zone $\left(i_{f}\right)$. The first two gradients, $i_{P B}$ and $\boldsymbol{i}_{R V G}$ are directly estimated from the hydraulic head distribution in the main aquifer (Fig. 11) as: $1.2 \times 10^{-3} \mathrm{~m} / \mathrm{m}$ and $0.4 \times 10^{-3} \mathrm{~m} / \mathrm{m}$ respectively. If the Peel Boundary Fault Zone is fitted in and a fault zone width of 5 meters is assumed $i_{f}$ follows as $640 \times 10^{-3} \mathrm{~m} / \mathrm{m}$. The Groundwater Map of the Netherlands (TNO-NITG, 1974a) indicates that the main aquifer on the Peel Block has a transmissibility value of around $1100 \mathrm{~m}^{2} /$ day.

Two situations for the transmissibility distribution in the model are considered. 1) the contrast in gradient between the aquifer on the Peel Block and the Roer Valley Graben is fully explained by a difference in transmissibility between the two blocks; and 2) the same contrast is completely explained by assuming discharge in the fault zone while the transmissibilities in the Peel Block $\left(\boldsymbol{T}_{\boldsymbol{P B}}\right)$ and Roer Valley Graben $\left(\boldsymbol{T}_{R V G}\right)$ are considered to be equal. In either case the transmissibility of the Peel Block is fixed $1100 \mathrm{~m}^{2} /$ day.

Case 1 ; When the observed gradients are fitted in the first case (no discharge in the fault zone), it follows from equation (7) that $\boldsymbol{T}_{\boldsymbol{R} N G}$ must equal 3300 $\mathrm{m}^{2} /$ day when $\boldsymbol{T}_{\boldsymbol{P B}}$ equals $1100 \mathrm{~m}^{2} /$ day. The transmissibility of the Peel Boundary Fault Zone $\left(\boldsymbol{T}_{\boldsymbol{f}}\right)$ is about $2.1 \mathrm{~m}^{2} /$ day. The equivalent fault resistance in this case follows from equation (5). If $\boldsymbol{D}$ is estimated as $25 \mathrm{me}-$ ters (from Fig. 10) and the width of the fault zone (w) as 5 meters, the equivalent fault resistance $c$ equals 59 days.

Case 2; In order to explain the observed difference

a.

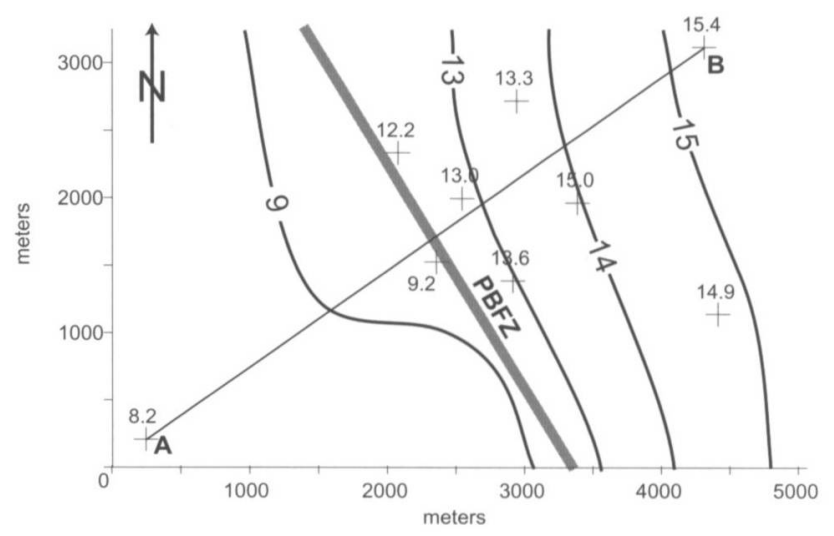

b.

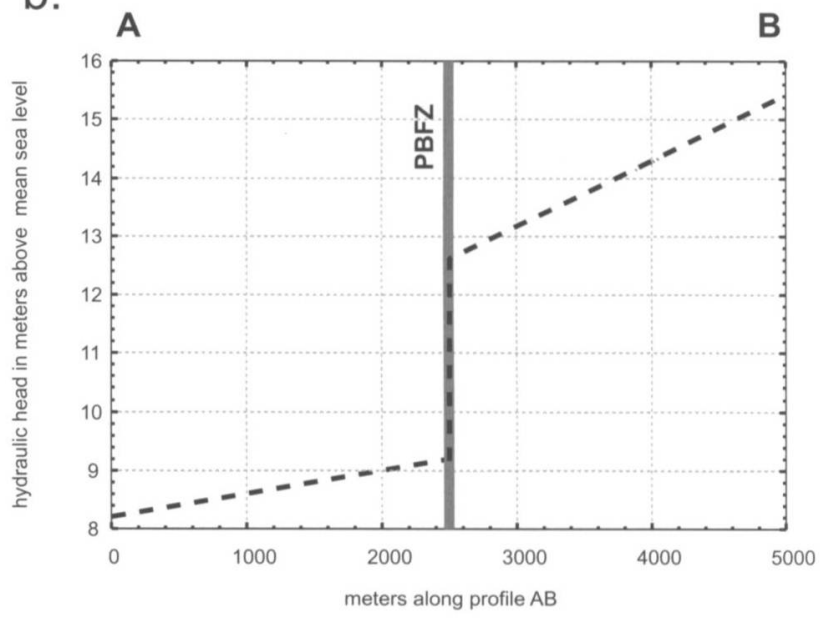

Fig. 11a\&b. Hydraulic head distribution (above mean sea level) in the main aquifer near the Peel Boundary Fault Zone (PBFZ) near the village of Uden (average over 1995) in map view (11a). Isohypses of hydraulic head are based on modeling results by Stuurman \& Atari (1997). The shift of hydraulic gradient over the Peel Boundary Fault is visualized in a cross section $(\mathrm{A}-\mathrm{B} ; 11 \mathrm{~b})$. 
in hydraulic gradient assuming that $\boldsymbol{T}_{R V G}=\boldsymbol{T}_{P B}=$ $1100 \mathrm{~m}^{2} /$ day on either side of the Peel Boundary Fault, groundwater fluxes must be different between the two blocks. The difference can be explained by incorporating discharge in the fault zone by following equation (7). It follows that the specific discharge $\left(\boldsymbol{q}_{r}\right)$ i.e. the product of $\boldsymbol{R}_{\boldsymbol{f}}$ and $\boldsymbol{w}$, in the Peel Boundary Fault Zone must be $0.9 \mathrm{~m}^{2} /$ day. In the latter case, $\boldsymbol{T}_{f}$ is found to be around $1.4 \mathrm{~m}^{2} /$ day ( 89 days). In the area on the Peel Block, close to the Peel Boundary Fault Zone, discharge is observed as surface seepage.

The two cases as described above, can be considered as two end-members of a range of possible hydraulic parameters that can explain the observed hydraulic head gradients. Fig. 12 shows the relation between the calculated values of the specific discharge over the fault zone $\left(\boldsymbol{q}_{f}\right)$, resistance of the fault zone (c) and the transmissibility in the Roer Valley Graben $\left(\boldsymbol{T}_{K V G}\right)$ in the interval $1100-3300 \mathrm{~m}^{2} /$ day.

The fault resistance of around 75 days that follows from gradient analysis implies that the hydraulic conductivity $(\boldsymbol{K})$ of the fault zone material is about 0.1 $\mathrm{m} /$ day. The undeformed material of the main aquifer has an estimated conductivity of around $60 \mathrm{~m} /$ day. This implies that the fault zone material has a hydraulic conductivity that is reduced with more than 2 orders of magnitude.

A one-dimensional gradient analysis provides a first estimate of fault zone hydraulic properties. The resistance of around 75 days for the Peel Boundary Fault Zone that was found in the above analysis, is in strong contrast to the value of 1500 days that was calculated by Stuurman \& Atari (1997) based on a numerical model of the system. This discrepancy is probably due to the fact that the numerical model incorporates

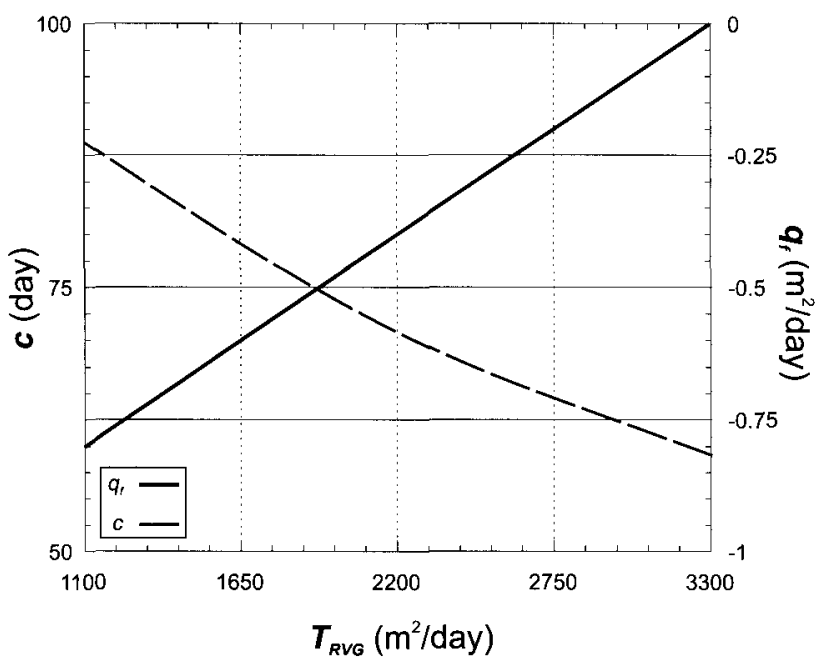

Fig. 12. Relation between the transmisibilityin the Roer Valley Graben $\left(\boldsymbol{T}_{R v G}\right)$, fault resistance $(\boldsymbol{c})$ and the specific discharge $\left(\boldsymbol{q}_{f}\right)$ in the fault zone. The transmisibilityof the aquifer on the Peel Block $\left(T_{P B}\right)$ is assumed to be $1100 \mathrm{~m}^{2} /$ day. more terms than horizontal groundwater flow only. More research is needed to elucidate the relative contribution of these variables in order to bring both models in closer agreement.

\section{The Peel Boundary Fault Zone near the village of Neer}

Near the village of Neer, a trench was opened over the Peel Boundary Fault Zone in the framework of paleo-seismological studies (Van den Berg et al., 2002). Here, in-situ observations on the micro-morphology of the fault zone were made in combination with a detailed profile of the hydraulic head gradients over the fault zone in the upper phreatic aquifer (Figs 13a \& b).

The top layer consists of fine-grained fluvio-aeolian sands (Nuenen Group) with a thickness of about 8-9 m.

The Peel Boundary Fault Zone has a small fault

$$
\text { a. }
$$

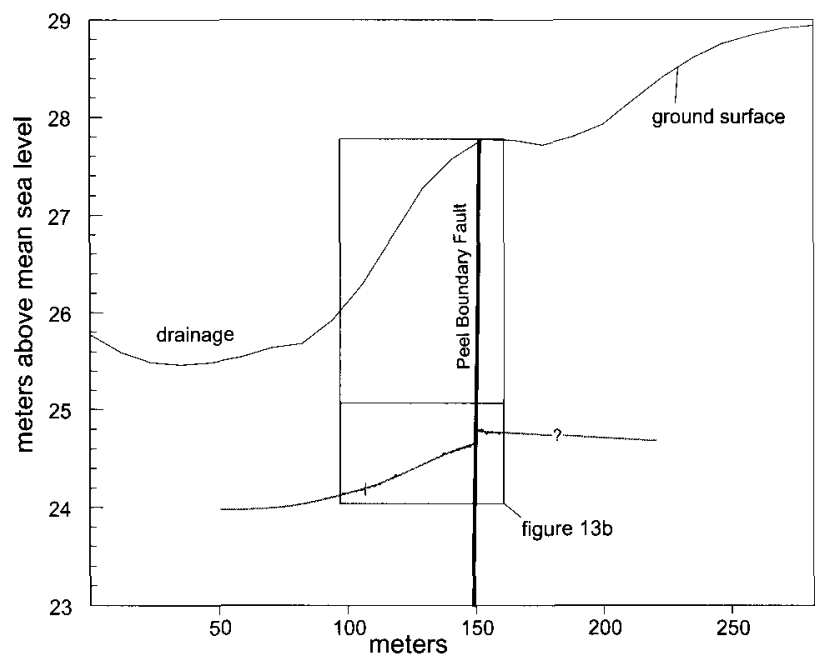

b.

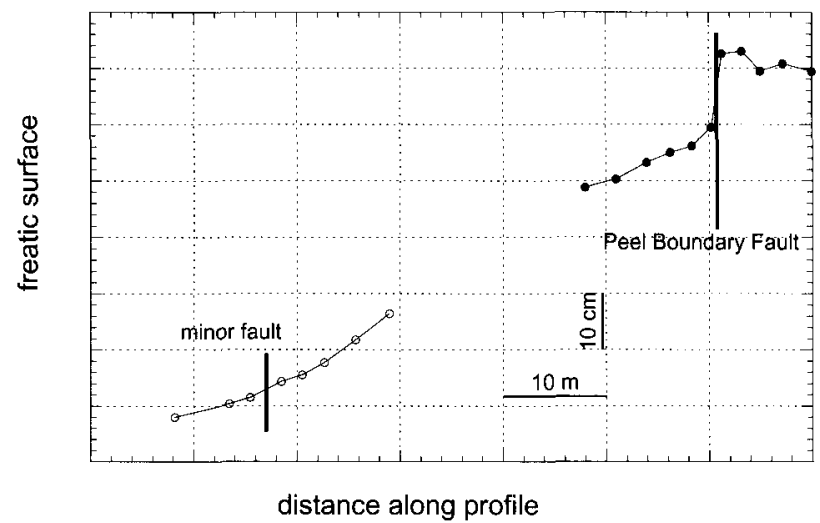

Fig. 13a\&b. Section of groundwater levels over the Peel Boundary Fault Zone near the village of Neer; for location see Fig. 2. Observations were done in shallow boreholes in a trenched outcrop. 


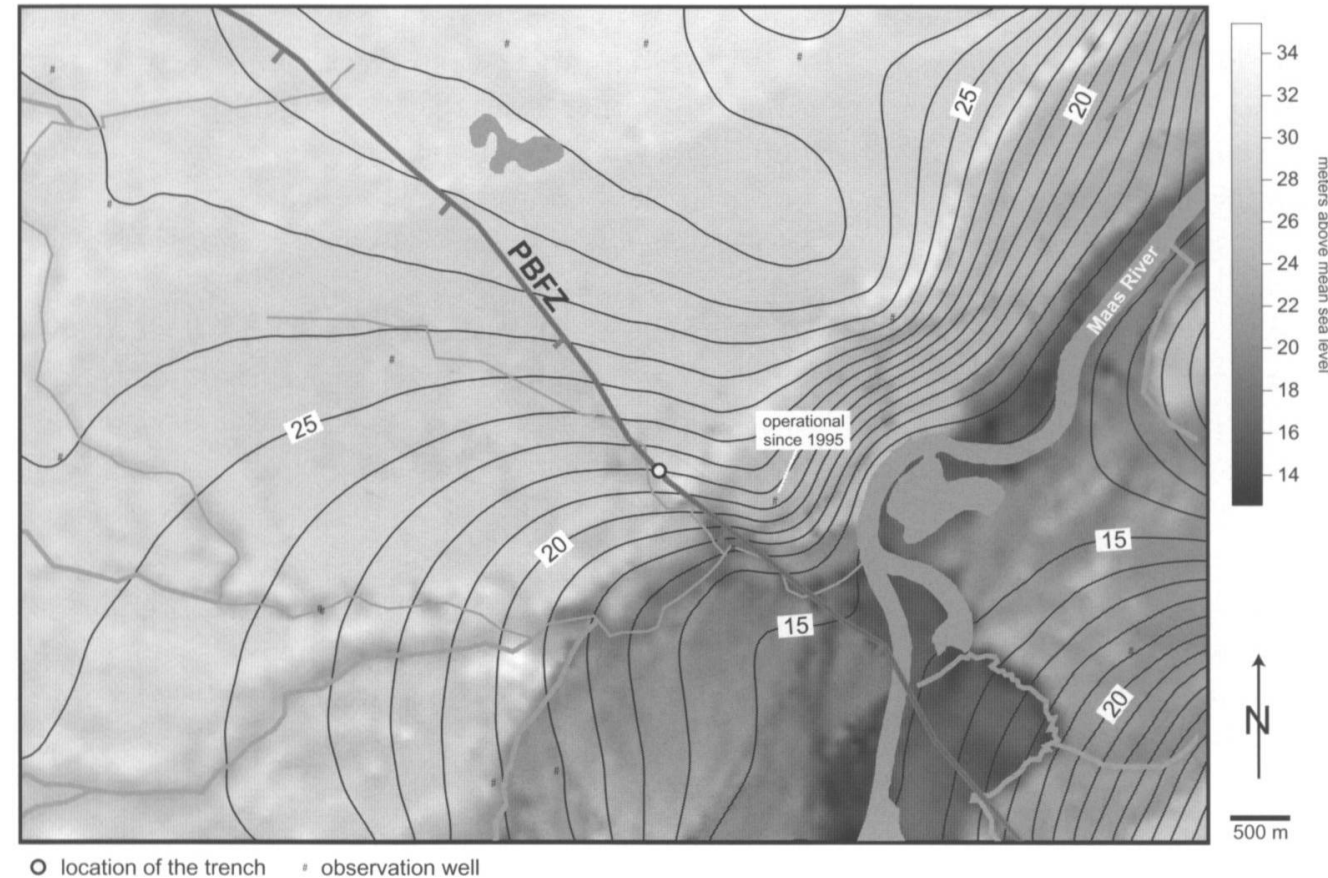

Fig. 14. Regional groundwater flow pattern superimposed on the topographic height of the area, in the vicinity of the site of Fig. 12 (Peel Boundary Fault Zone $=$ PBFZ). This shows that the primary control on groundwater flow to be discharge to the Meuse River with a possible local deflection across the southern side of the PBFZ.

scarp in the topography but this is far less pronounced than it is near the village of Uden. The observations in the trench show that the fault is limited to a one metre wide zone. Over this distance, going from the Peel Boundary Fault Zone into the Roer Valley Graben, the phreatic groundwater level drops about $15 \mathrm{~cm}$. Just below the groundwater table in the trench, massive iron concretions were found along the fault plane. Similar to the situation near Uden, these iron concretions indicate that near the fault reduced groundwater discharges to the surface where it is subsequently oxidized. Therefore, these concretions are probably only limited to the zone close to the water table.

Coarse sands and gravels (Veghel Formation) form the regional main aquifer below silts and fine sands (Nuenen Group). According to the groundwater map of the Netherlands (TNO-NITG, 1974b), in this area, hydraulic heads in the phreatic top layer are closely coupled to the hydraulic heads in the underlying aquifer. The direction of regional groundwater flow can at first instance be estimated from the same map; this indicates that near the trench, groundwater flow is semi-parallel to the Peel Boundary Fault Zone. However, one observation well that was placed more recently (Fig. 14) was not yet operational during the compilation of the groundwater map. Inclusion of this new data point allows for a somewhat different interpretation of the flow pattern; it suggests that flow is likely to be more normal to the Peel Boundary Fault Zone. The uncertainty on the direction of groundwater flow near the fault zone makes it difficult to place our small-scale observations in a larger regional scale context.
The section of phreatic groundwater levels as recorded perpendicular to the Peel Boundary Fault Zone (Fig. 13b) suggests that the fault zone is acting as a groundwater devide at this shallow depth, since groundwater flow is away from the fault zone on both sides of the fault. The gradient of groundwater flow on the footwall block is very small, while on the hanging wall the gradient is significant. If groundwater flow is assumed more or less perpendicular to the fault zone, recharge of the fault zone must take place. Observations on the trench walls show that recharge may indeed take place on the Peel Block, in a zone flanking the main fault plane. There, conjugate sets of small $\mathrm{cm}$-wide deformation bands have developed as a result of fault activity. These deformation bands have a spacing of about $50 \mathrm{~cm}$ and their occurrence extents about $2 \mathrm{~m}$ onto the footwall. Also, these small deformational structures are internally bleached which is interpreted to indicate that they form preferential paths to vertical infiltration of water (Miedema \& Jongmans, 2002).

If a hydraulic conductivity of around $10 \mathrm{~m} /$ day is assumed for fine sand, a transmissibility value of 80 $\mathrm{m}^{2} /$ day follows for the upper phreatic aquifer. The thickness of this top layer does not significantly change across the fault zone at this location. So, the transmissibility of the aquifers on either side of the fault zone is assumed to be $80 \mathrm{~m}^{2} / \mathrm{day}$. A fit of the observed hydraulic heads (Fig. 15) using the same procedure as discussed above and assuming a fault zone width of one meter based on observations in the trench, shows that the fault resistance must be around 4 days while the fault zone is recharged at a rate of 


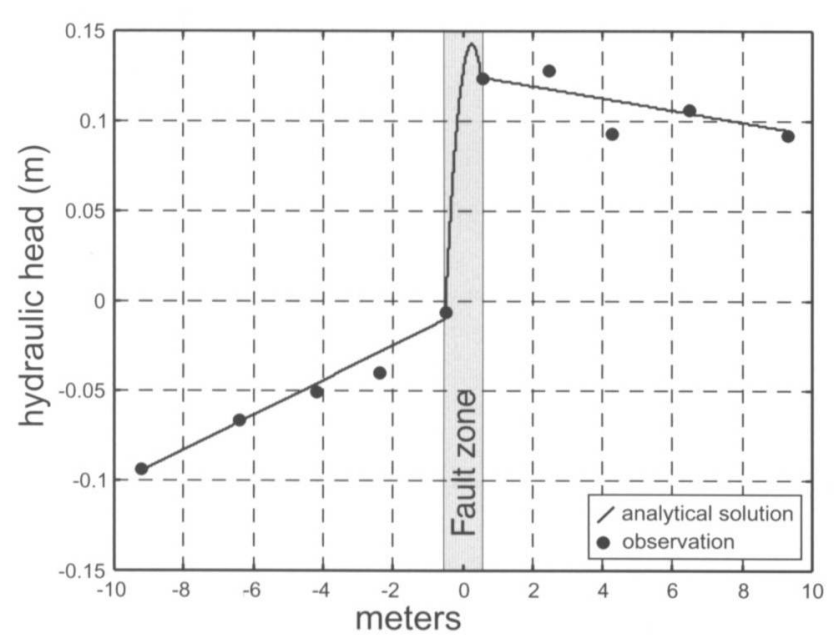

Fig. 15. Fitted hydraulic head profile over the observed data in the trench using an analytical solution. To explain the observed gradients a recharge of the Peel Boundary Fault Zone of around 1 $\mathrm{m}^{2} /$ day is needed in combination with a fault resistance of 4 days $\left(\boldsymbol{D}_{\text {fault }}=8 \mathrm{~m}\right)$. The transmissibility of the flanking aquifers is here assumed to equal $80 \mathrm{~m}^{2} /$ day. Hydraulic head values are normalized so that the hydraulic head losses on the left and right-hand side of the origin of the system are equal.

$1 \mathrm{~m}^{2} /$ day. This fault resistance value is far less than observed at the site near the village of Uden. This is reasonable, since the resistance of only the upper aquifer is calculated here. Probably, fault resistance will increase with depth since the effectiveness of most important fault sealing mechanisms is based on the amount of throw along the fault plane in combination with depth.

\section{Discussion and Conclusions}

The impact of faults on groundwater movements in an active rift system like the Roer Valley Rift System is clearly demonstrated in the lignite mining area in Germany where strong groundwater extraction enhances their effects. Studies in the Netherlands, which show the influence of faults are sparse. This is because only detailed mapping of the hydraulic head distribution can reveal locally anomalous high or low hydraulic head gradients. Examples from previous research show that faults may have a pronounced effect on aquifer structure on regional as well as on local scale, which may be essential to studies related to groundwater management, groundwater contamination and its environmental impact. In order to improve groundwater flow models, the exact relationship between tectonic structures (i.e. faults) and hydrogeology needs to be clarified. Therefore, more extensive and quantitative analysis of the impact of faulting on the hydrogeological buildup of the Roer Valley Rift System is needed, from regional to field scale.

Regionally important faults in the Roer Valley Rift
System, like the Feldbiss and Peel Boundary Fault Zones, have an obvious regional hydrogeological impact since they separate larger hydrogeological units. The effect of individual smaller faults is more difficult to assess. Smaller secondary faults will be more frequent and therefore will probably have a strong cumulative effect on internal aquifer structure and small-scale groundwater systems. Observation wells are often too widely spaced to give sufficient information to make a reconstruction of the flow pattern near faults. It is expected that the cumulative effect of a set of small faults, all having a similar orientation that is induced by the regional tectonic stress field, should result in a regional anisotropy of hydraulic conductivity. Thorough analysis of pumping tests or dense groundwater monitoring networks would be needed to reveal such a regional anisotropy. Hydraulic head patterns and their fluctuation over time should give information on the underlying geological buildup of an area and could reveal structures that would otherwise be difficult to detect. However, recognition of steps in the hydraulic head profile resulting from faults, requires detailed information because these kind of subtle jumps in hydraulic head are easily overlooked when data are interpolated.

An important conclusion of the present analysis is that faults in the Roer Valley Rift System can form strong barriers to horizontal groundwater flow while vertical groundwater flow may be enhanced. The hydrogeological build-up of fault zones is thus strongly anisotropic. At the location of faults normally separated aquifers can be hydraulically coupled which makes the vertical interchange of groundwater between these aquifers possible. This sort of mechanism can have important implications to the spread of contaminated groundwater which may intrude into other aquifers through vertical flow along faults.

\section{Acknowledgements}

W.C. Haneberg is thanked for providing additional derivations of analytical solutions to describe groundwater flow over idealized fault zones. Vincent Post is thanked for assistance during fieldwork. Elmer van den Berg is thanked for critical comments. Dick Edelman (Tilburg Water Supply Company) is acknowledged to provide data for the Tilburg site. The municipality of Tilburg is thanked for providing the aerial photograph of Fig. 4. Kees Maas (KIWA; Research center for water and related nature and environmental aspects) and James Underschultz (CSIRO Petroleum) are thanked for providing reviews of the manuscript which greatly helped to improve the contents of this paper. 


\section{References}

Bon, J, 1968. The configuration of the groundwater table. In: Determination of the optimum combination of water management systems in areas with a microrelief. Institute for Land and Water management research: $188 \mathrm{pp}$.

Csónka, J., 1968. Report on the possibilities for application of the geothermal method in the Netherlands [in Dutch]. Netherlands Institute for Applied Geosciences, Delft, OS 92-40A: 59 pp.

Darby, D., Haszeldine, R.S. \& Couples, G.D., 1996. Pressure cells and pressure seals in the UK Central Graben. Marine and Petroleum Geology 13: 865-878.

De Glee, G.J. \& Brandenburg, S., 1926. Report on the possible expansion of the 'Prise d'Eau' and the pumping activities of the Tilburg Water Supply Company [in Dutch]: $107 \mathrm{pp}$.

De Vries, J.J., 1974, Groundwater flow systems and stream nets in the Netherlands. PhD thesis, Amsterdam, Vrije Universiteit: 226 pp.

De Vries, J.J., 1994. Dynamics of the interface between streams and groundwater systems in lowland areas, with reference to stream net evolution. Journal of Hydrology 155: 39-56.

Ernst, L.F. \& De Ridder, N.A., 1960. High resistance to horizontal ground-water flow in coarse sediments due to faulting. Geologie en Mijnbouw 39: 66-85.

Geluk, M.C., Duin, E.J.T., Dusar, M. \& Rijkers, R.H.B., 1994, Stratigraphy and tectonics of the Roer Valley Graben. Geologie en Mijnbouw 73: 129-141.

Haneberg, W.C., 1995. Steady state groundwater flow across idealized faults. Water Resources Research 31: 1815-1820.

Harper, T.R. \& Lundin, E.R., 1997. Fault seal analysis: reducing our dependance on empiricism. In: Møller-Pedersen P. and Koestler A.G. (eds) Hydrocarbon seals: Importance for exploration and production, NPF Special Publication 7, Elsevier, Singapore: 149-165,

Houtgast, R.H. \& Van Balen, R.T., 2000. Neotectonics of the Roer Valley Rift System, the Netherlands. Global and Planetary Change 27: 131-146.

Knott, S.D., 1993. Fault seal Analysis in the North Sea. American Association of Petroleum Geologists Bulletin 77: 778-792.

Miedema, R. \& Jongmans, T., 2002. Soil formation in Late Glacial Meuse sediments related to the Peel Boundary Fault activity. Netherlands Journal of Geosciences/Geologie en Mijnbouw 81 (1): 71-81.

Paulissen, E., Vandenberghe, J. \& Gullentops, F., 1985.The Feldbiss fault in the Maas valley bottom (Limburg, Belgium). Geologie en Mijnbouw 64: 79.
Stuurman, R.J. \& Atari, R.H., 1997. The Groundwater situation around the 'Wijstgronden' near Uden. NITG-TNO, 97-212(a): $67 \mathrm{pp}$.

Stuurman, R.J., 2000. Transboundary hydrogeological processes in the southern Netherlands. In: Evaluation and protection of groundwater resources. IAH Conference Wageningen 2000, IAH (Delft): 59-77.

TNO-NITG, 1974a, Groundwater map of the Netherlands; 1:50.000 - 's-Hertogenbosch; 45 West - 45 East [in Dutch]. Netherlands Institute for Applied Geosciences (NITG), Delft.

Van Balen R.T., Van Bergen, F, de Leeuw, C., Pagnier, H., Simmelink, H., van Wees, J.D. \& Verweij, J.M., 2000. Modelling the hydrocarbon generation and migration in the West Netherlands Basin, the Netherlands. Geologie en Mijnbouw/Netherlands Journal of Geosciences 79: 29-44.

Van den Berg, M., Vaneste, K., Dost, B., Lokhorst, A., Van Eijk, M. $\&$ Verbeeck, K., 2002. Paleoseismic investigations along the Peel Boundary Fault: geological setting, site selection and trenching results. Netherlands Journal of Geosciences 81: 39-60

Van Zanten, E., 1996. Risk Analysis of the Gilze-Rijen fault system [in Dutch], Internal Report, Tilburg, Tilburg Water Supply Company: $77 \mathrm{pp}$.

Vandenberghe, J., 1982. Geoelectric investigations of a fault system in Quartenary deposits, Geophysical Prospecting 30: 879-897.

Vandenberghe, J., 1990. Morphological effects of Pleistocene faulting in unconsolidated sediments (Central Graben, Netherlands). Zeitschrift fur Geomorphologie N.F. Heft 1: 113-124.

Visser, W.C., 1948. The problem of the "Wijstgronden" (Badlands) [in Dutch], Journal of the Dutch Society of Earth Sciences 65: 798-823.

Wallbraun, A., 1992. Impact of the block bounding faults in the Lower Rhine Embayment on groundwater discharge [in German]. PhD-thesis, Aachen, Rheinisch-Westfälischen Technischen Hochschule: 118 pp.

Willemse, E.J.M., Pollard, D.D. \& Aydin, A., 1996. Three-dimensional analyses of slip distributions on normal fault arrays with consequences for fault scaling. Journal of Structural Geology 18: 295-309.

Winstanley, A.M., 1993. A review of the triassic play in the Roer Valley Graben, SE onshore Netherlands. In: Parker J.R. (ed.), Petroleum Geology of Northwest Europe, Proceedings of the 4th Conference: 595-607.

Ziegler, P.A., 1994. Cenozoic rift system of western and central Europe: an overview. Geologie en Mijnbouw 73: 99-127.

Zijl, W., 1993. Scale analysis in groundwater hydrology. Brussels, Vrije Universiteit Brussel: 328 pp. 